\title{
Assessment of Morpho-Dynamics through Geospatial Techniques within the Padma-Meghna and Ganges-Jamuna River Confluences, Bangladesh
}

\author{
Md. Yousuf Gazi ${ }^{1}$ (1) Himel Roy ${ }^{1} \cdot$ Md. Bodruddoza Mia ${ }^{1} \cdot$ Syed Humayun Akhter ${ }^{1}$
}

Received: 31 July 2020 / Accepted: 11 September 2020 / Published online: 6 October 2020

(c) The Author(s) 2020

\begin{abstract}
Bangladesh is a low-lying riverine country with the mighty Ganges-Brahmaputra-Meghna (GBM) major river system including their abundant tributaries and distributaries. Land erosion-accretion is a very common phenomenon in this riverine country. This process extensively erodes huge productive landmasses at the river confluence zones every year. The main objective of this study was to understand the confluence morpho-dynamics and identify the vulnerable areas near the Padma-Meghna Confluence (PMC) and Ganges-Jamuna confluence (GJC) due to confluence shifting and erosion-accretion phenomenon of those rivers. The present study utilized multi-temporal Landsat satellite images from 1972 to 2019 approximately ten years of interval. Results showed that the PMC indicated frequent variation in migration trend towards NW from 1972 to 1980, SE from 1980 to 2010, and then reversed towards NW direction from 2010 to 2019. On the other hand, the GJC confluence point moved NW direction $(2.37 \mathrm{~km}$ ) from the year 1972 to 1980, but from 1980 to 2019, the confluence shifted towards the SE direction. Due to the migration dynamics, huge changes happened in width and sand bars area of both confluences. In PMC, confluence width increased remarkably indicating erosive flow during 1972-1980, then progressively shortened up to 2019, indicating accretion. In contrast, GJC shows a significant accretional trend over the 47 years. The sand bar area of the PMC increased about $147.09 \mathrm{~km}^{2}$ throughout the study period. But, GJC shows an opposite scenario where the total sand bar area decreased about $51.02 \mathrm{~km}^{2}$ in the same period. From the vulnerability study of erosion-accretion scenarios, it is predicted that Paturia Ferry Ghat area, Aricha Ferry Ghat area, Arua, Baruria, Dashkin Saljana, Bhadiakola, Masundia, Khanganj and Nyakandi areas near GJC and Chandpur sadar, Srimandi, Sakhua, Bilaspur and char Atra near PMC are highly vulnerable zones. The outputs of the study will enable policy makers to take necessary measures to reduce the erosional severity on both confluence zones and could also provide a basis for proper land management.
\end{abstract}

Keywords River confluence $\cdot$ Morpho-dynamics $\cdot$ Padma-Meghna $\cdot$ Ganges-Jamuna $\cdot$ Geospatial techniques $\cdot$ Bangladesh

\begin{abstract}
Abstrakt
Bangladesch ist ein tief gelegenes Flussland mit dem mächtigen Flusssystem Ganges-Brahmaputra-Meghna (GBM), einschließlich seiner reichlich vorhandenen Neben- und Nebenflüsse. Landerosion - Akkretion ist in diesem Flussland ein sehr verbreitetes Phänomen. Dieser Prozess untergräbt jedes Jahr große produktive Landmassen in den Zusammenflusszonen des Flusses. Das Hauptziel dieser Studie ist es, die Morphodynamik der Konfluenz zu verstehen und die gefährdeten Gebiete in der Nähe der Padma-Meghna-Konfluenz (PMC) und der Ganges-Jamuna-Konfluenz (GJC) aufgrund von Flussverschiebungen und Erosionsakkretionsphänomenen zu identifizieren. In der vorliegenden Studie wurden multitemporale LandsatSatellitenbilder von 1972 bis 2019 im Abstand von etwa zehn Jahren verwendet. Das Ergebnis zeigt, dass die PMC von 1972
\end{abstract}

Md. Yousuf Gazi

yousuf.geo@du.ac.bd

Himel Roy

himelroy101@gmail.com

Md. Bodruddoza Mia

bodruddoza@du.ac.bd
Syed Humayun Akhter

shakhter@du.ac.bd

1 Department of Geology, University of Dhaka, Dhaka, Bangladesh 
bis 1980 häufige Schwankungen des Migrationstrends in Richtung NW, von 1980 bis 2010 in Richtung SE und von 2010 bis 2019 in Richtung NW andeutet. Andererseits bewegte sich der GJC-Konfluenzpunkt in NW-Richtung (2,37 km) von 1972 bis 1980, aber von 1980 bis 2019 hat sich der Zusammenfluss in Richtung SE verschoben. Aufgrund der Migrationsdynamik kam es zu großen Veränderungen in der Breite und den Sandbänken des Zusammenflusses. In PMC nahm die Konfluenzbreite zwischen 1972 und 1980 merklich zu, was auf einen erosiven Fluss hinweist, und verkürzte sich dann schrittweise bis 2019, was auf eine Akkretion hinweist. Im Gegensatz dazu zeigte GJC in den 47 Jahren einen signifikanten Akkretionstrend. Die Sandbankfläche des PMC nahm während des gesamten Untersuchungszeitraums um 147,09 km2 zu. GJC zeigt jedoch ein entgegengesetztes Szenario, bei dem die gesamte Sandbankfläche im gleichen Zeitraum um etwa 51,02 km2 abnahm. Aus der Vulnerabilitätsstudie von Erosionsakkretionsszenarien wird vorausgesagt, dass das Gebiet Paturia Ferry Ghat, Aricha Ferry Ghat, Arua, Baruria, Dashkin Saljana, Bhadiakola, Masundia, Khanganj und Nyakandi in der Nähe von GJC und Chandpur Sadar, Srimandi, Sakhua Bilaspur und Char Atra in der Nähe von PMC sind sehr gefährdete Zonen. Die Ergebnisse der Studie sollen es uns ermöglichen, die notwendigen Maßnahmen zu ergreifen, um den Schweregrad der Erosion an beiden Zusammenflüssen zu verringern und eine Grundlage für eine ordnungsgemäße Landbewirtschaftung zu schaffen.

Schlüsselwörter Flusskonfluenz · Morpho-Dynamik · Padma-Meghna · Ganges-Jamuna · Geodaten-Techniken · Bangladesch

\section{Introduction}

River confluences are the nodal points in the river system where main river channels are amalgamated, which in turn, may employ a significant control over the river migration and morphology (Richards 1980; Best and Rhoads 2008). Bangladesh is known as a low-lying riverine country with mighty Ganges-Brahmaputra-Meghna (GBM) major river system. Land erosion-accretion and channel migrations are very common phenomena in Bangladesh, taking place on both banks of a river. This process extensively wears away huge prolific land areas at the river confluence zones due to the intricate processes of sediment-water interactions. The regions close to the study area (Padma-Meghna and Ganges-Jamuna confluence) are facing extensive erosion problems adjacent to the several important urbanized and economically developed regions (Ahmed et al. 2014).

Several comprehensive field assessments have already been done basically on the flow process in the confluence zones (Biron et al. 1993; De Serres et al. 1999; Baranya et al. 2015). The hydro-morphodynamic evolution of mountain river confluences was documented by Guillén-Ludeña et al (2016). Confluence morphodynamics has been studied mostly on the small fluvial channels (Mosley 1976; Biron et al. 1993; Boyer et al. 2006) but with the advent of recent technologies, large-scale fluvial channels are now the most focusing arena of scientists around the world (Ashworth et al. 2000; Parsons et al. 2007; Sambrook Smith et al. 2009). Many researchers across the world documented confluence morpho-dynamics of small, large river (Parsons et al. 2008; Hackney et al. 2018; Stevaux et al. 2009), gravelly braided river confluence (Wheaton et al. 2013) and tidal channel confluences (Ginsberg et al. 2009; Xie et al. 2018). Current advance in remote sensing and GIS enables us understand the extent to which river confluences are dynamic, planform characteristics and decadal evolution of the confluence points (Trigg et al. 2012; Lewin and Ashworth, 2014; Mount et al. 2013). In recent time, many aspects of river confluence like sediment, flow structure, and morpho-dynamics are being focused throughout the world to understand the process and mitigate the possible hazards (Ali et al. 2019; Szupiany et al. 2019; Sankey et al. 2018; Rhoads and Johnson 2018). In the river confluence zone, erosion-accretion is considered a prime focal point. Erosional process interrupts water quality and consumption for human and industry and river ecosystems (Benda et al. 2004; Gazi et al. 2020; Leite et al. 2012). River capacity decreases due to sediment accumulation that finally results in the modification of morphodynamics in the river confluence zone (Julien et al. 2010; Mohammed et al. 2011). This reduced capacity and tributaries discharge intensify flood risks due to heavy precipitation (Wang et al. 2016).

Some remote sensing and GIS-based studies emphasized on the dynamic behavior of the world major confluences including GBM river system confluence (Dixon et al. 2018; Szupiany et al. 2019). More focusing work on the river bank erosion and shifting at Chandpur near lower Meghna River has also been done using satellite images (Nath et al. 2013). It is worth to mentioning that important initiatives have been taken at different times to assess the erosion-accretion scenarios in the river banks of Bangladesh (CEGIS 2003; SWMC 2002; IWM 2005). Very few studies conducted on the morpho-dynamics behavior of confluence systems in Bangladesh till now.

The prime objective of this research is to assess the morpho-dynamics and shifting direction of the confluences and interpret the vulnerable zones surrounding the confluences as erosion and accretion are very prominent in the bank of the confluences. Understanding the morpho-dynamics of 
these areas will be highly efficient for managing land areas close to the river confluence zones.

\section{Study Area}

The study area covers Padma-Meghna confluence at Chandpur town, Chandpur district and Ganges-Jamuna confluence at Aricha Ghat, Rajbari district, which are two major confluences in Bangladesh (Fig. 1). The confluences are morphologically very dynamic in nature during monsoon and post-monsoon season since the water discharge and sedimentation rate are very high because of low elevation. Sand, silt, and clay are comprising the sediments of the Ganges-Brahmaputra-Meghna (GBM) river system at the downstream part in the Bengal basin, Bangladesh, which is accumulating under unidirectional energy conditions (Datta and Subramanian 1998).

The Padma is a very large alluvial river with the longitudinal slope of about $5 \mathrm{~cm}$ per km (Halcrow 1993), bed material is in the range D $16=0.02 \mathrm{~mm}, \mathrm{D} 50=0.09 \mathrm{~mm}$ and D84 $=0.2 \mathrm{~mm}$ and average discharge is $28.4\left(10^{3}\right.$ $\mathrm{m}^{3} / \mathrm{s}$ ) (FAP 24 1996). Meghna can be categorized as a meandering river with an average discharge of about 33 $\left(10^{3} \mathrm{~m}^{3} / \mathrm{s}\right)$ and bed material size D50 is about $0.09 \mathrm{~mm}$. Ganges river is one of the major sediment dispersal systems (mostly suspended sediment) in the Bengal basin with a channel length of about $2974 \mathrm{~km}$ (Wasson, 2003). Jamuna is a braided river with an average braid plain width of $11 \mathrm{~km}$ and a flow depth of around $5 \mathrm{~m}$ (Sarker and Thorne 2006).

The average rainfall in the PMC and GJC regions is, respectively, $53.39 \mathrm{~mm}$ and $58.79 \mathrm{~mm}$ throughout the year. The water level varies in Jamuna, Ganges, Padma and Meghna river, respectively, 13.6-19.1 (mPWD), 5.4-13.7 (mPWD), 1.5-5.5 (mPWD) and 1.5-6 (mPWD), but during the monsoon and flood period, there is no specific range to remark (Sarkar et al. 2003).

\section{Materials and Methods}

Georeferenced multi-spectral satellite images from 1972 to 2019 (in the same month and season) were used to analyze the planform morpho-dynamics of the confluence points, and images were acquired from USGS (https://earthexplorer.usgs.

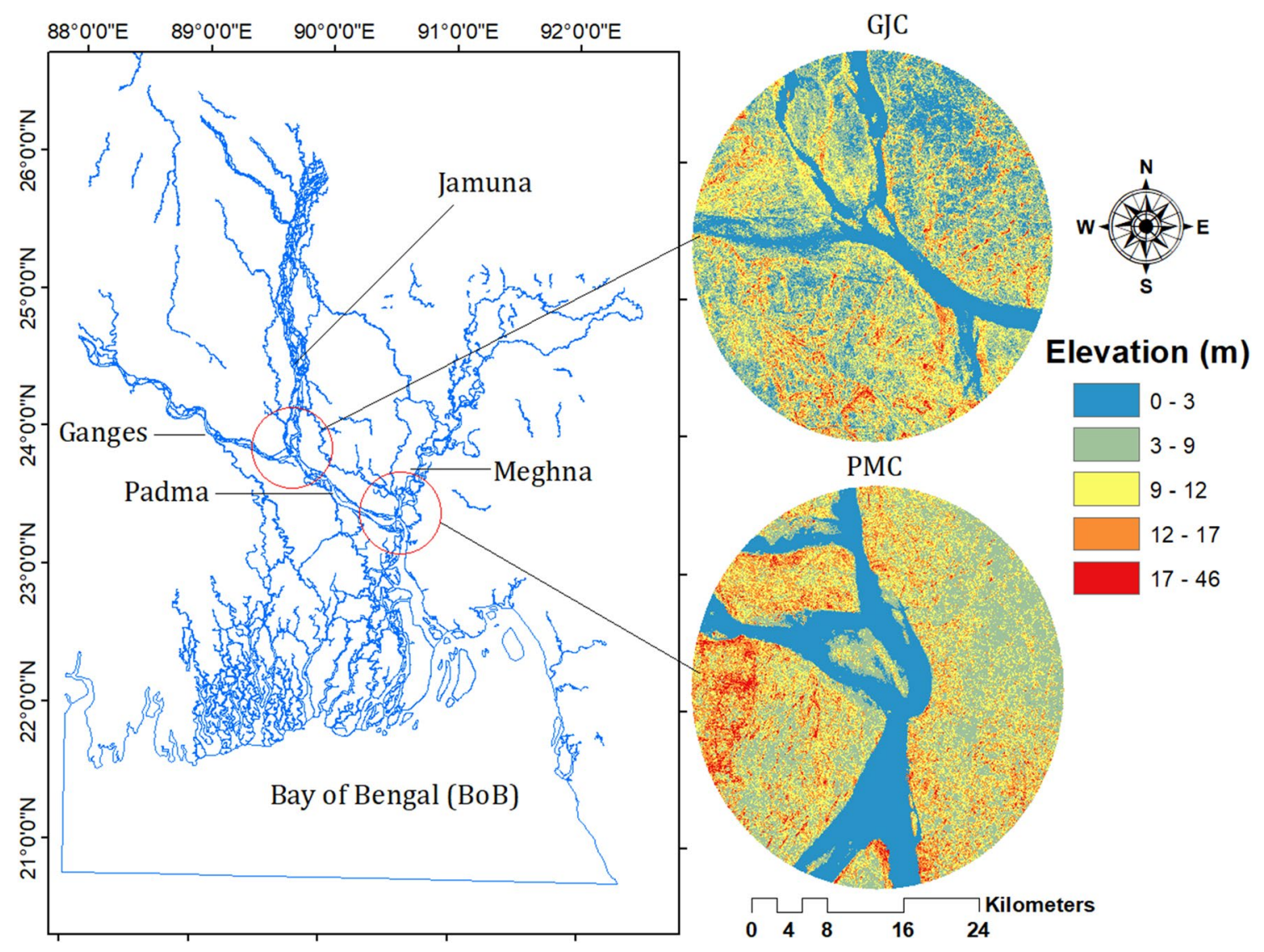

Fig. 1 Map showing the study area (Confluence points). GJC indicates Ganges-Jamuna confluence and PMC stands for Padma-Meghna confluence 
Table 1 Satellite images (used in this study) with their sensor, acquisition dates and spatial resolution (meter)

\begin{tabular}{|c|c|c|c|c|c|c|}
\hline \multirow[t]{2}{*}{ Date of acquisition } & \multirow[t]{2}{*}{ Sensor } & \multirow[t]{2}{*}{ Spatial resolution } & \multicolumn{2}{|l|}{ GJC } & \multicolumn{2}{|l|}{ PMC } \\
\hline & & & Row & Path & Row & Path \\
\hline 28/01/1972 & MSS & $60 \times 60$ & 44 & 148 & 44 & 147 \\
\hline 02/01/1980 & MSS & $60 \times 60$ & 43 & 148 & 44 & 147 \\
\hline 07/01/1990 & $\mathrm{TM}$ & $30 \times 30$ & 43 & 138 & 44 & 137 \\
\hline 19/01/2000 & $\mathrm{TM}$ & $30 \times 30$ & 43 & 138 & 44 & 137 \\
\hline 30/01/2010 & $\mathrm{TM}$ & $30 \times 30$ & 43 & 138 & 44 & 137 \\
\hline 23/01/2019 & OLI/TIRS & $30 \times 30$ & 43 & 138 & 44 & 137 \\
\hline
\end{tabular}

gov/) (Table 1). The images were corrected radiometrically and geometrically. Geospatial software Erdas Imagine 14 and ArcGis 10.3 were utilized in this study for data analysis and interpretation. The individual bands of acquiring sensors have been added together by "Layer stacking". To ease the processing and enhance spatial resolution, all the bands were stacked except the thermal band. Study area was selected for each image finally by "Subset" process. Using the ruler function in ArcGis, the confluence width was measured. The accuracy of the ArcGis ruler function was assessed by taking 100 repeat measurements at a known distance at the same virtual altitude and image resolution of the study area.

Modified normalized difference water index (MNDWI) was calculated to differentiate between land and water boundary. Subsequently that was used to extract the erosional-accretional boundary and to locate the exact position of the confluence points. NDWI is generally calculated using ( $\mathrm{Xu} 2006)$ :

MNDWI $=($ Green - SWIR $) /($ Green + SWIR $)$

Here,

SWIR = reflectance of short-wave infrared region and

Green $=$ reflectance of green regions of the used Landsat images

Confluence angle was measured using the approach of Hackney and Carling (2011). The middle points of the channel center lines united and the angles of intersection ( $A 1$ and $A 2)$ were measured by means of a protractor with degree increments (Lublowe 1964). A3 was determined using the following formula:
$A 3=360-(A 1+A 2)$

\section{Results and Discussion}

\subsection{Confluence Point Shifting}

The major concern of the study is to enumerate the confluence point shifting. There was a rapid shifting of the confluence points over the years. Significant migration had been occurred in both confluence points affecting the surrounding region of the study area. The migration mainly occurred for the erosional and accretional activities of the river bank. High flow rate causes erosional action and low flow rate causes accretional activity.

\subsubsection{Shifting of the PMC}

The PMC moved about $9.17 \mathrm{~km}$ toward $\mathrm{N} 17.69^{\circ} \mathrm{W}$ from 1972 to 1980 (Table 2). In the next 10 years, the confluence migration was reversed and moved around $2.73 \mathrm{~km}$ toward $\mathrm{S} 13.79^{\circ}$ E. From 1980 to 2010, the confluence migrated through the SE direction. But from 2010 to 2019, the confluence point was reversed and had chosen the direction from SE to NW. Eventually, from 1972 to 2019, the confluence point was migrated toward $\mathrm{S} 36.6^{\circ} \mathrm{E}$ and traveled about $6.77 \mathrm{~km}$. Tracking the shifting trend of this confluence point is very crucial for the presence of important urbanized
Table 2 Direction and distance summary of confluence migration (PMC) from 1972 to 2019

\begin{tabular}{|c|c|c|c|c|c|}
\hline \multicolumn{3}{|c|}{ From 1972 to 2019} & \multicolumn{3}{|c|}{ From 1972 to 2019} \\
\hline Year & Direction & Distance $(\mathrm{km})$ & Year & Direction & Distance $(\mathrm{km})$ \\
\hline 1972-1980 & $\mathrm{N} 17.69^{\circ} \mathrm{W}$ & 9.17 & 1972-1980 & $\mathrm{N} 17.69^{\circ} \mathrm{W}$ & 9.17 \\
\hline 1980-1990 & $\mathrm{S} 13.79^{\circ} \mathrm{E}$ & 2.73 & 1972-1990 & $\mathrm{N} 19.35^{\circ} \mathrm{W}$ & 6.44 \\
\hline 1990-2000 & $\mathrm{S} 36.37^{\circ} \mathrm{E}$ & 6.54 & $1972-2000$ & $\mathrm{~N} 65.12^{\circ} \mathrm{E}$ & 1.92 \\
\hline 2000-2010 & $\mathrm{S} 18.38^{\circ} \mathrm{E}$ & 8.23 & 1972-2010 & $\mathrm{S} 32.1^{\circ} \mathrm{E}$ & 8.25 \\
\hline 2010-2019 & $\mathrm{N} 12.59^{\circ} \mathrm{W}$ & 1.59 & 1972-2019 & $\mathrm{S} 36.6^{\circ} \mathrm{E}$ & 6.77 \\
\hline
\end{tabular}




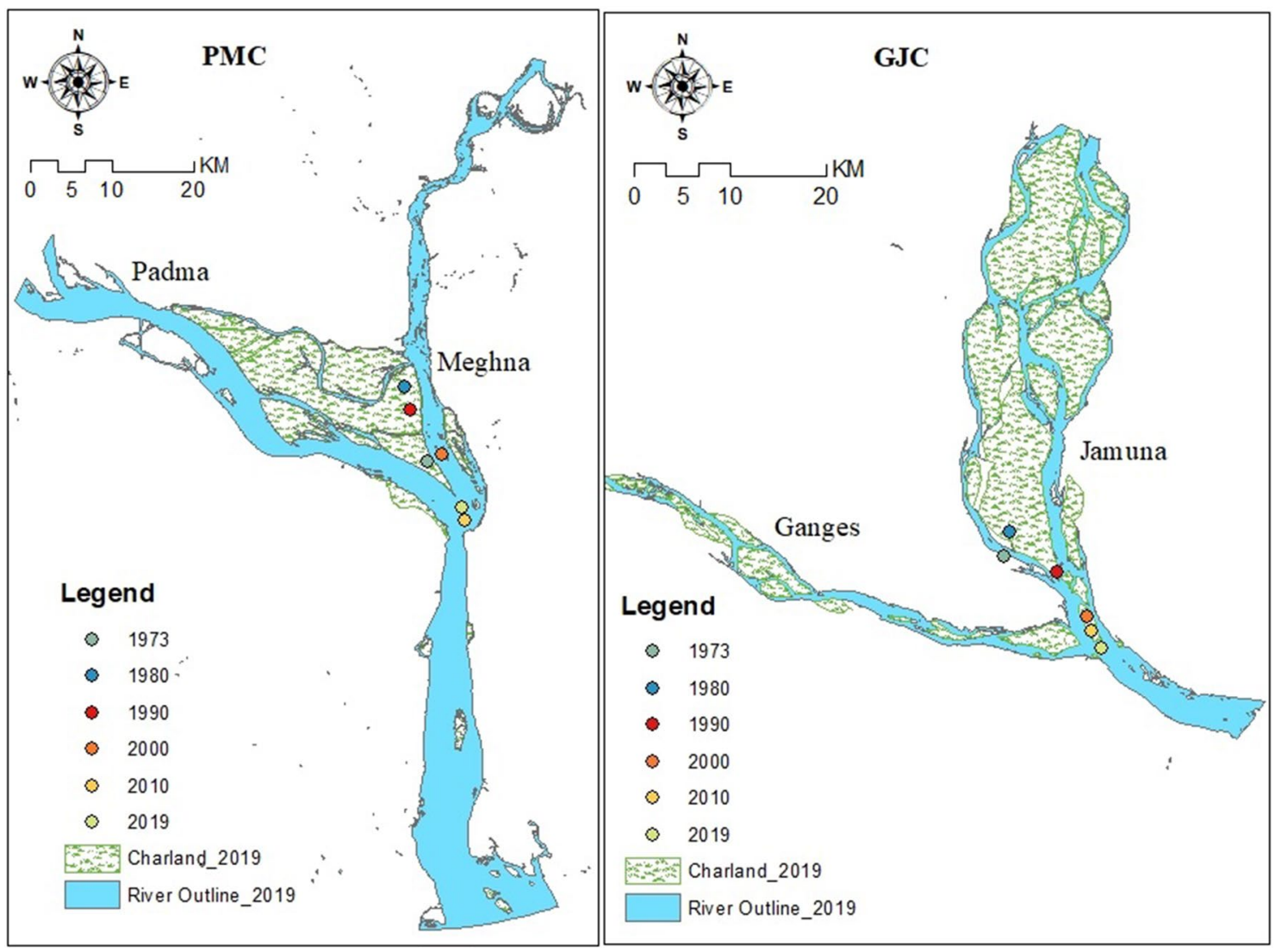

Fig. 2 Temporal planform shifting of PMC and GJC from 1972 to 2019

region that is very close to the eastern part of the confluence (Fig. 2).

\subsubsection{Shifting of the GJC}

The GJC point was migrated about $2.37 \mathrm{~km}$ towards NE direction from the year 1972 to 1980 , and from 1980 to 2019 , the confluence point migrated towards the SE direction (Table 3). So, the migration is continuing towards the SE direction. The major migration was occurred from 1980 to 1990 , migrated almost $6.07 \mathrm{~km}$ towards S $50.55^{\circ}$ E. From 1972 to 2019 , the confluence shifted around $13.15 \mathrm{~km}$ towards $\mathrm{S} 46.56^{\circ} \mathrm{E}$. This confluence followed a specific trend from 1972 to 2019 towards $\mathrm{S} 46.56^{\circ} \mathrm{E}$, about $13.15 \mathrm{~km}$. This tremendous movement of the confluence point indicates the erosional activity of the riverbank in the SE direction (Fig. 3).
Table 3 Direction and distance summary of confluence migration (GJC) from 1972 to 2019

\begin{tabular}{|c|c|c|c|c|c|}
\hline \multicolumn{6}{|l|}{ GJC shifting } \\
\hline \multicolumn{3}{|c|}{ From 1972 to 2019} & \multicolumn{3}{|c|}{ From 1972 to 2019} \\
\hline Year & Direction & Distance $(\mathrm{km})$ & Year & Direction & Distance $(\mathrm{km})$ \\
\hline 1972-1980 & $\mathrm{N} 14.27^{\circ} \mathrm{E}$ & 2.37 & $1972-1980$ & $\mathrm{~N} 14.27^{\circ} \mathrm{E}$ & 2.37 \\
\hline 1980-1990 & $\mathrm{S} 50.55^{\circ} \mathrm{E}$ & 6.07 & $1972-1990$ & $\mathrm{~S} 73.46^{\circ} \mathrm{E}$ & 5.50 \\
\hline 1990-2000 & $\mathrm{S} 33.45^{\circ} \mathrm{E}$ & 5.27 & $1972-2000$ & $\mathrm{~S} 53.88^{\circ} \mathrm{E}$ & 10.12 \\
\hline 2000-2010 & $\mathrm{S} 19.08^{\circ} \mathrm{E}$ & 1.54 & $1972-2010$ & $\mathrm{~S} 49.47^{\circ} \mathrm{E}$ & 11.42 \\
\hline 2010-2019 & $\mathrm{S} 28.15^{\circ} \mathrm{E}$ & 1.83 & 1972-2019 & $\mathrm{S} 46.56^{\circ} \mathrm{E}$ & 13.15 \\
\hline
\end{tabular}



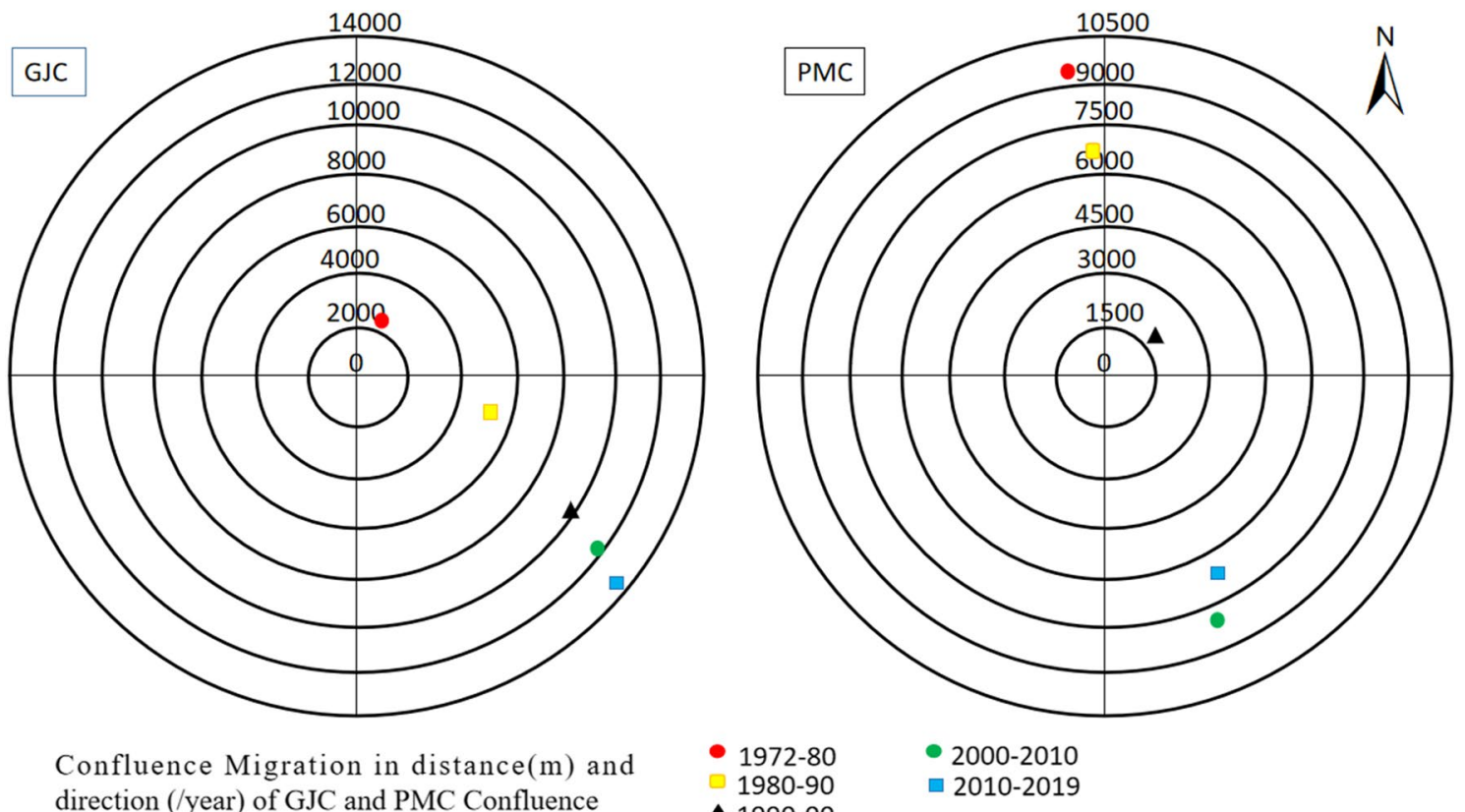

Confluence Migration in distance $(\mathrm{m})$ and direction (/year) of GJC and PMC Confluence

- 1990-00

Fig. 3 Diagram showing the directional migration of confluence point (PMC and GJC) with 10 years interval from 1972 to 2019

Table 4 Confluence width in the PMC and GJC from 1972 to 2019

\begin{tabular}{lll}
\hline Year & $\begin{array}{l}\text { Confluence width (PMC) } \\
(\mathrm{Km})\end{array}$ & $\begin{array}{l}\text { Confluence } \\
\text { width (GJC) } \\
(\mathrm{km})\end{array}$ \\
\hline 1972 & 6.87 & 8.10 \\
1980 & 12.64 & 8.50 \\
1990 & 11.63 & 5.38 \\
2000 & 9.37 & 2.69 \\
2010 & 6.03 & 3.01 \\
2019 & 6.98 & 2.80 \\
\hline
\end{tabular}

\subsection{Confluence Width}

The change in the width of river confluences both in the PMC and GJC infers the erosional and accretional trends surrounding the confluence zones along with river banks.

\subsubsection{Temporal Variation of Width in the PMC}

Variation in confluence width was very prominent in this zone. During the years of 1972, 1980, 1990, 2000, 2010, and 2019, the calculated confluence widths were, respectively, $6.87 \mathrm{~km}, 12.64 \mathrm{~km}, 11.63 \mathrm{~km}, 9.37 \mathrm{~km}, 6.03 \mathrm{~km}$, and $6.98 \mathrm{~km}$. From the year 1972 to 1980 , the confluence width dramatically enlarged from 6.87 to $12.64 \mathrm{~km}$ accounting $5.77 \mathrm{~km}$ widening. It can be suggested that within this time frame, a tremendous amount of erosion

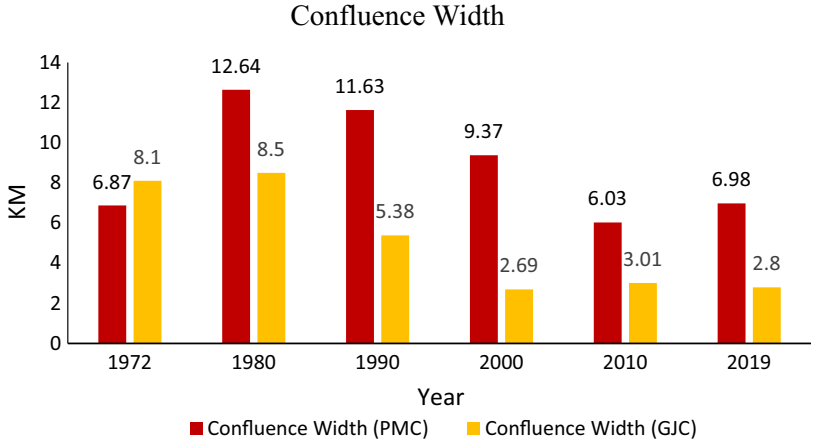

Fig. 4 Showing the changes of the Confluence Width for both PMC and GJC from 1972 to 2019

occurred which indicates the high-water flow rate. However, from 1990 to 2010 , confluence width decreased from 11.63 to $6.03 \mathrm{~km}$ representing a $5.3 \mathrm{~km}$ narrowing that indicated low water flow rate (Table 4). After that, the confluence width increased up to $6.98 \mathrm{~km}$ till 2019. So, the confluence width increased about $11 \mathrm{~km}$ throughout the study period.

\subsubsection{Temporal Variation of Width in the GJC}

The change of confluence width was also very pronounced in this region. Throughout the years of 1972, 1980, 1990, 2000, 2010, and 2019, the documented confluence width was about $8.1 \mathrm{~km}, 8.5 \mathrm{~km}, 5.38 \mathrm{~km}, 2.69 \mathrm{~km}, 3.01 \mathrm{~km}$, and $2.8 \mathrm{~km}$, respectively (Fig. 4). The maximum changes 
occurred from 1980 to 2000 . The width decreased by nearly $5.81 \mathrm{~km}$ over the 20 years. The maximum width recorded about $8.50 \mathrm{~km}$ in the year of 1980 . But, a slight increase in the confluence width occurred from 2000 to 2010. So, it can be expected that the confluence width might be decreased with time.

\subsection{Sandbar Morphodynamics at the Confluences}

The most important aspect of study areas is the dynamics of sandbar accumulation and recession. Mainly, sandbars are accumulating in the upstream channel of both confluences.

\subsubsection{Sandbar Morpho-dynamics at PMC}

There had been a rapid accumulation of sandbar in the PMC throughout the study period and redistribution of sandbars had also been noticed. Aerial extents of the

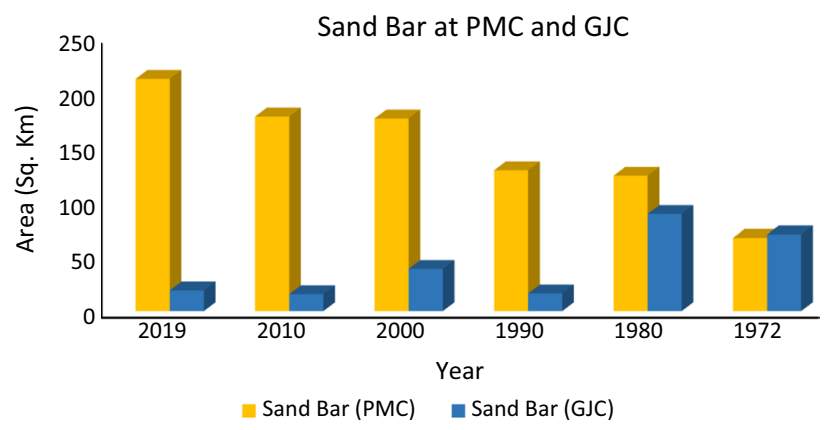

Fig. 6 Showing the distribution of sand bar at PMC and GJC from 1972 to 2019

sandbar in the confluence zone were $66.87 \mathrm{~km}^{2}, 123.58$ $\mathrm{km}^{2}, 128.54 \mathrm{~km}^{2}, 176.02 \mathrm{~km}^{2}, 177.86 \mathrm{~km}^{2}$ and 211.96 $\mathrm{km}^{2}$ for the years of 1972, 1980, 1990, 2000, 2010, and 2019 , respectively. Over the years, the study showed an increasing trend of sandbar accumulation in this confluence zone (Fig. 5). The total area increased from 1972 to

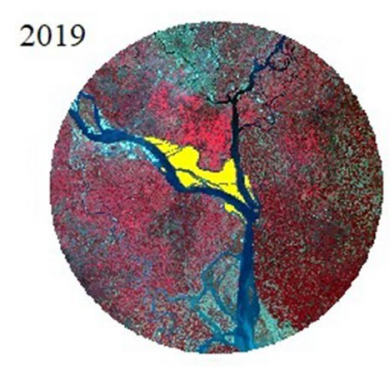

PMC
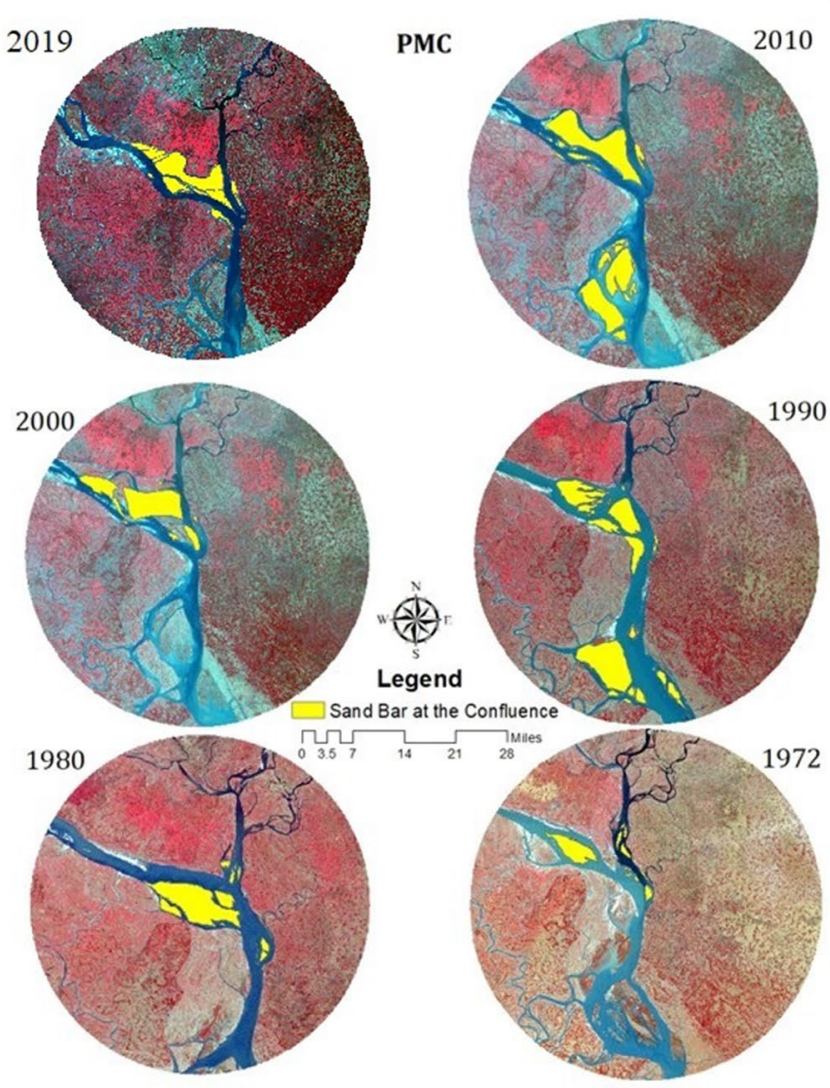

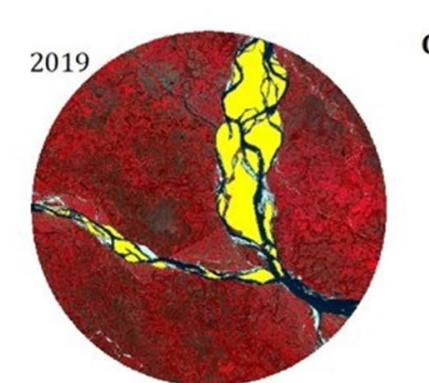

GJC
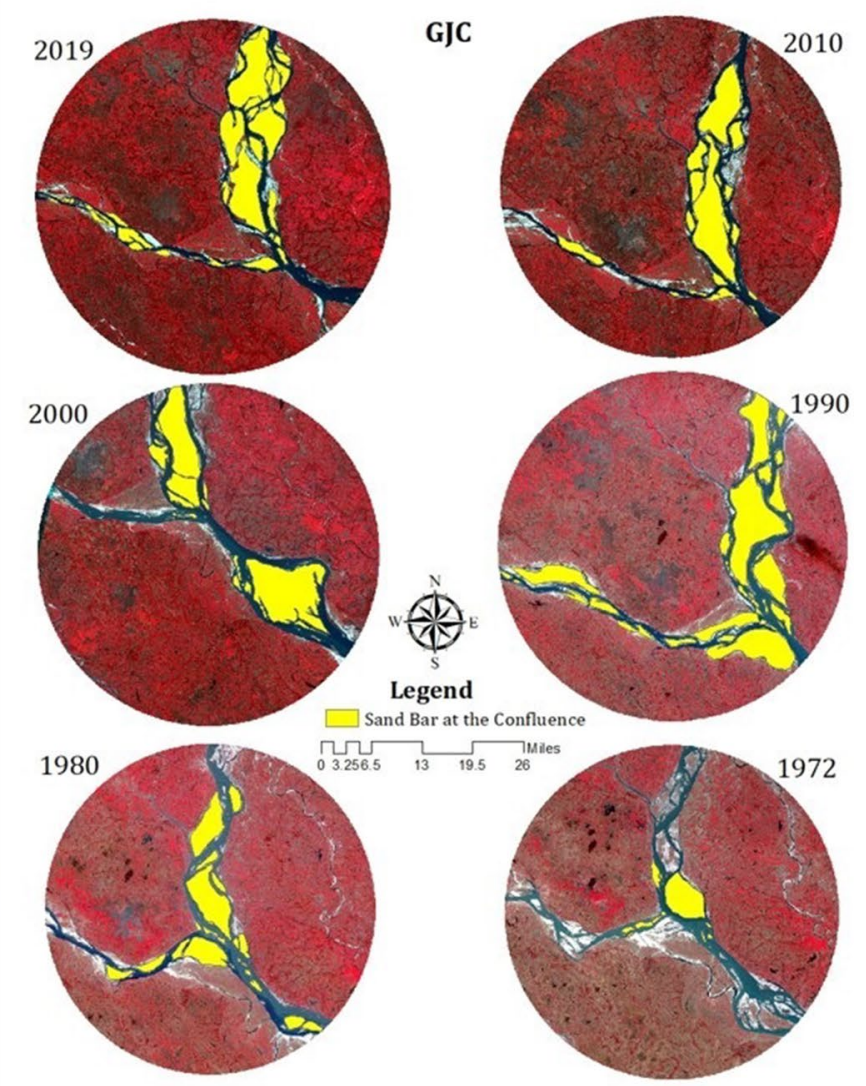

Fig. 5 Showing the distribution and dynamics of Sand Bar in the PMC and GJC from 1972 to 2019 
Table 5 Sand bar areal statistics of both Confluences (PMC and GJC) from 1972 to 2019

\begin{tabular}{cll}
\hline Year & $\begin{array}{l}\text { Sand bar } \\
(\mathrm{PMC}) \\
\left(\mathrm{km}^{2}\right)\end{array}$ & $\begin{array}{l}\text { Sand bar } \\
(\mathrm{GJC}) \\
\left(\mathrm{km}^{2}\right)\end{array}$ \\
\hline 2019 & 211.96 & 18.94 \\
2010 & 177.85 & 15.43 \\
2000 & 176.02 & 38.61 \\
1990 & 128.54 & 16.11 \\
1980 & 123.57 & 88.57 \\
1972 & 66.87 & 69.96 \\
\hline
\end{tabular}

2019 was around $145.09 \mathrm{~km}^{2}$ (Fig. 6). The major sandbar in this confluence zone is in the Padma river just above the confluence point which indicates that the flow
Table 6 Erosion-accretion statistics in the both confluences from 1972 to 2019

\begin{tabular}{llllll}
\hline Year & PMC & & & GJC \\
\cline { 2 - 3 } \cline { 5 - 6 } \cline { 5 - 6 } & $\begin{array}{l}\text { Erosion } \\
\text { (Sq. km) }\end{array}$ & $\begin{array}{l}\text { Accretion } \\
(\text { Sq. km) }\end{array}$ & & $\begin{array}{l}\text { Erosion } \\
\text { (Sq. km) }\end{array}$ & $\begin{array}{l}\text { Accretion } \\
(\text { Sq. km) }\end{array}$ \\
\hline 1972-1980 & 57 & 35 & 67 & 55 \\
$1980-1990$ & 62 & 35 & & 27 & 36 \\
$1990-2000$ & 73 & 4 & & 50 & 20 \\
$2000-2010$ & 83 & 43 & & 23 & 43 \\
$2010-2019$ & 89 & 40 & 69 & 21 \\
\hline
\end{tabular}

velocity through this Padma River is decreasing and the sediment flux is increasing day by day.
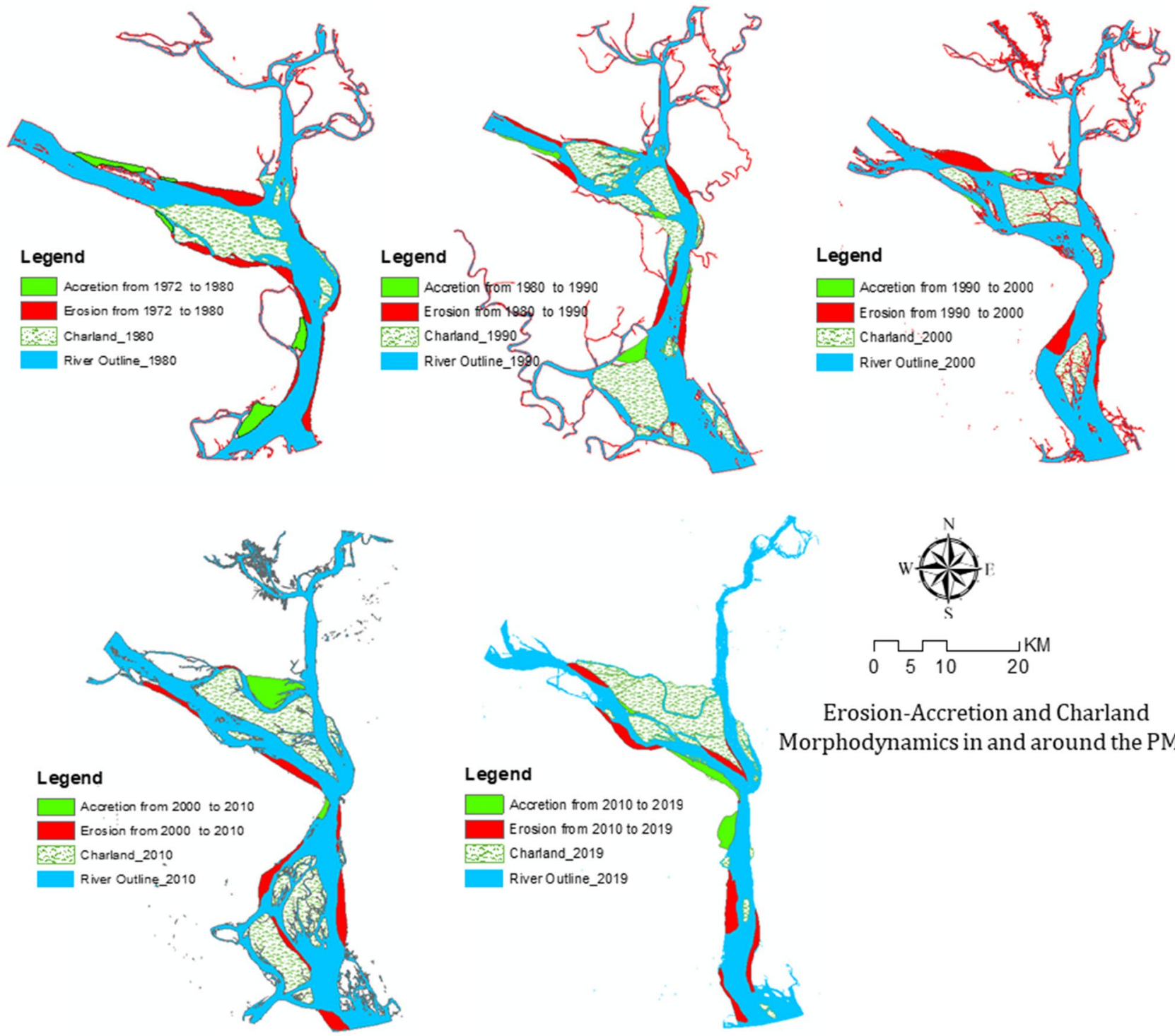

Erosion-Accretion and Charland Morphodynamics in and around the PMC

Fig. 7 Spatio-temporal erosion-accretion trend in and around the PMC from 1972 to 2019 


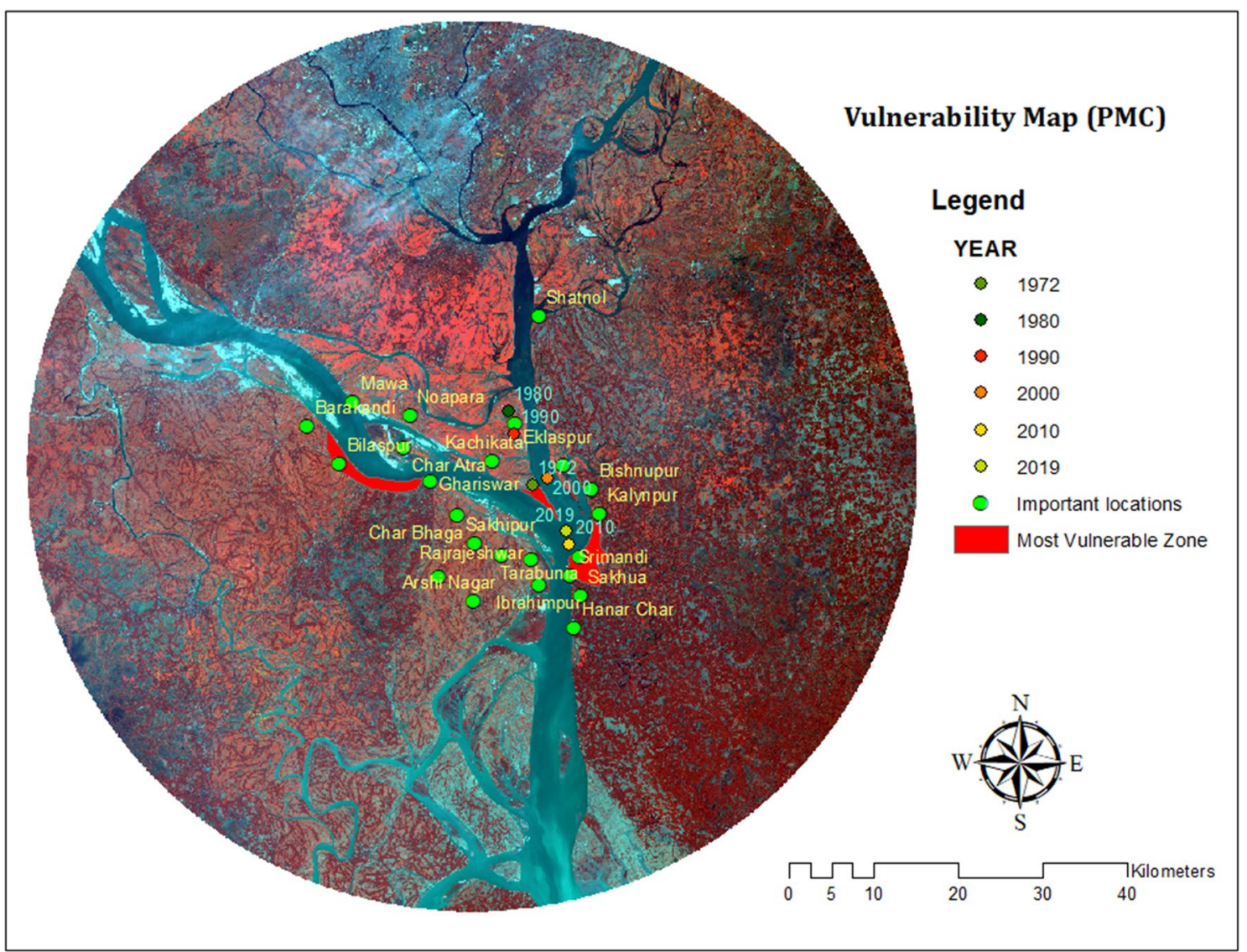

Fig. 8 Showing the most vulnerable zones around PMC due to shifting and erosional activities

\subsubsection{Sandbar Morpho-dynamics at GJC}

A huge change had also been observed in the sandbar area in the GJC throughout the study period. In the years of 1972, 1980, 1990, 2000, 2010 and 2019, sandbar occupied about $69.96 \mathrm{~km}^{2}, 88.57 \mathrm{~km}^{2}, 16.11 \mathrm{~km}^{2}, 38.61 \mathrm{~km}^{2}, 15.42 \mathrm{~km}^{2}$ and $18.94 \mathrm{~km}^{2}$ area, respectively (Table 5). The result identified a decreasing trend of the sandbar deposition from 1972 to 2019 in the GJC that was reverse to the PMC. From 1972 to 1980, sandbar area increased, but from 1980 to 1990, a huge decrease occurred, again from 1990 to 2000, sandbar area increased and then followed a decreasing trend up to 2019 (Fig. 5). The major sandbar in this confluence zone is in the upstream of both the Ganges and Jamuna rivers which indicates that the flow velocity of both rivers is very high in this confluence zone than the zone above the confluence point.

\subsection{Erosion-Accretion Surrounding the Confluence Zones}

Erosion-accretion is very prominent and has been continuing alternately along the banks of the river surrounding the confluence zones.

\subsubsection{Erosion-Accretion Surrounding the PMC}

In and around the PMC, the most erosion-prone period was 2010-2019 but erosion was most prominent in comparison with accretion in the period from 1990 to 2000 . It was very distinct that land loss due to erosional activities had been increasing (57-89 Sq. Km) compared to accretion from 1972 to 2019 at the PMC (Table 6). Throughout the study period, the right bank of the lower Padma River was the 


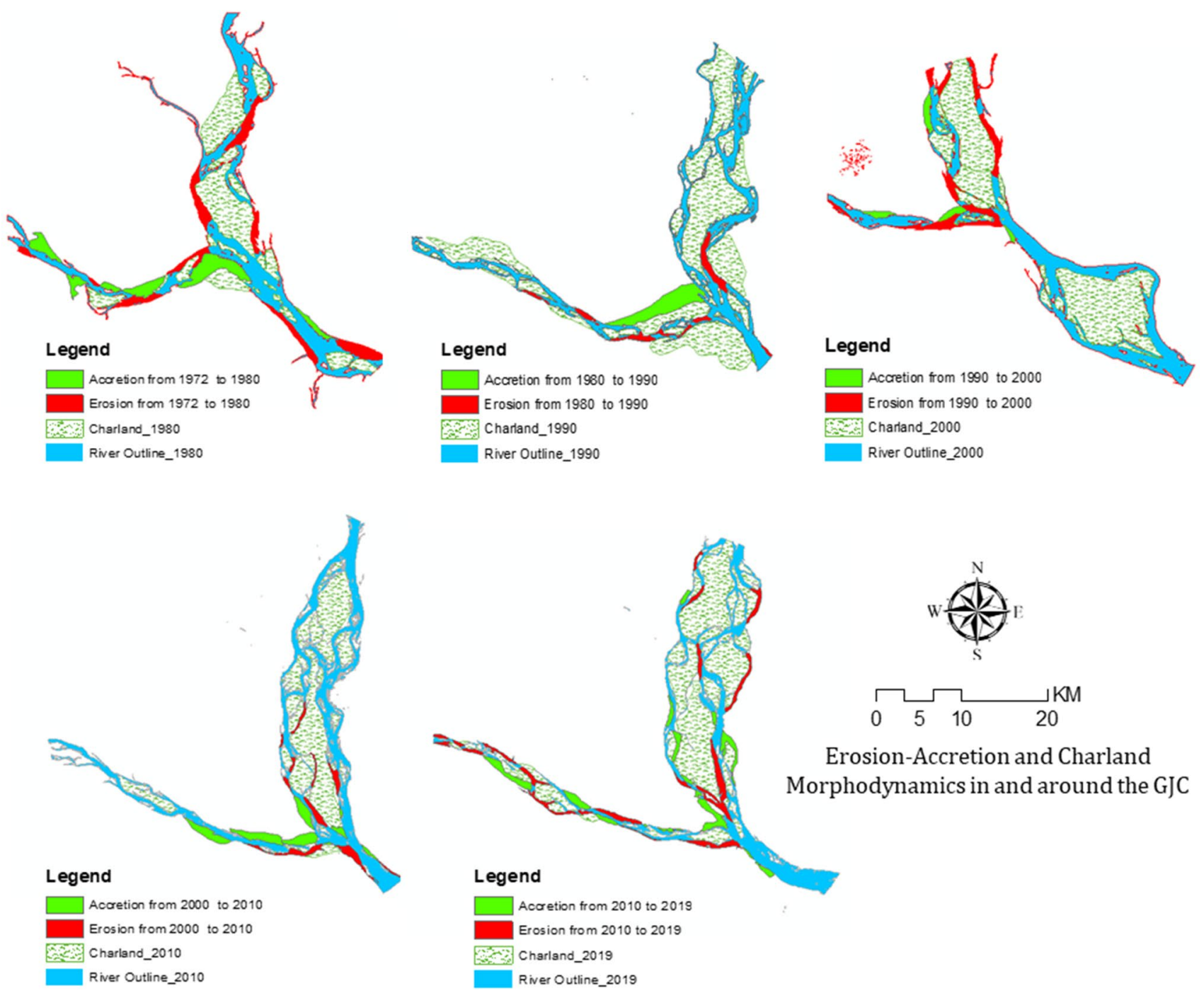

Fig. 9 Spatio-temporal erosion-accretion trend in and around the GJC from 1972 to 2019

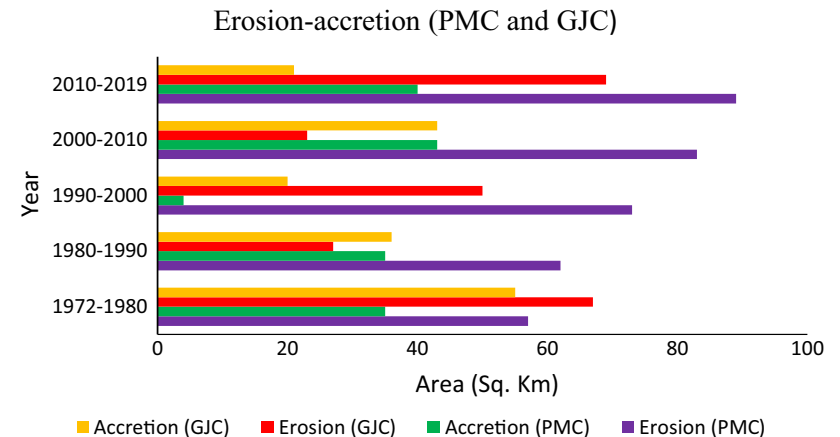

Fig. 10 Erosion-accretion pattern in the PMC and GJC with 10 years interval from 1972 to 2019 most unstable area on the left side of the confluence zone (Fig. 7). However, in the recent decades, the area has undergone accretional activities and erosion, mainly approaching the central charland area within the confluence zone. The upper part of the confluence is showing an accretional trend, whereas the lower part of the confluence signifies an erosional trend.

Based on the shifting trend and erosion-accretion, the most erosion-prone areas around the PMC are Sakhipur, Bilaspur, Chandpur sadar, Srimandi, Sakhua, and char Atra. Chandpur Sadar and Srimandi. The present erosional trend suggests that within the next few years, maximum parts of the area will be eroded into the river (Fig. 8). 


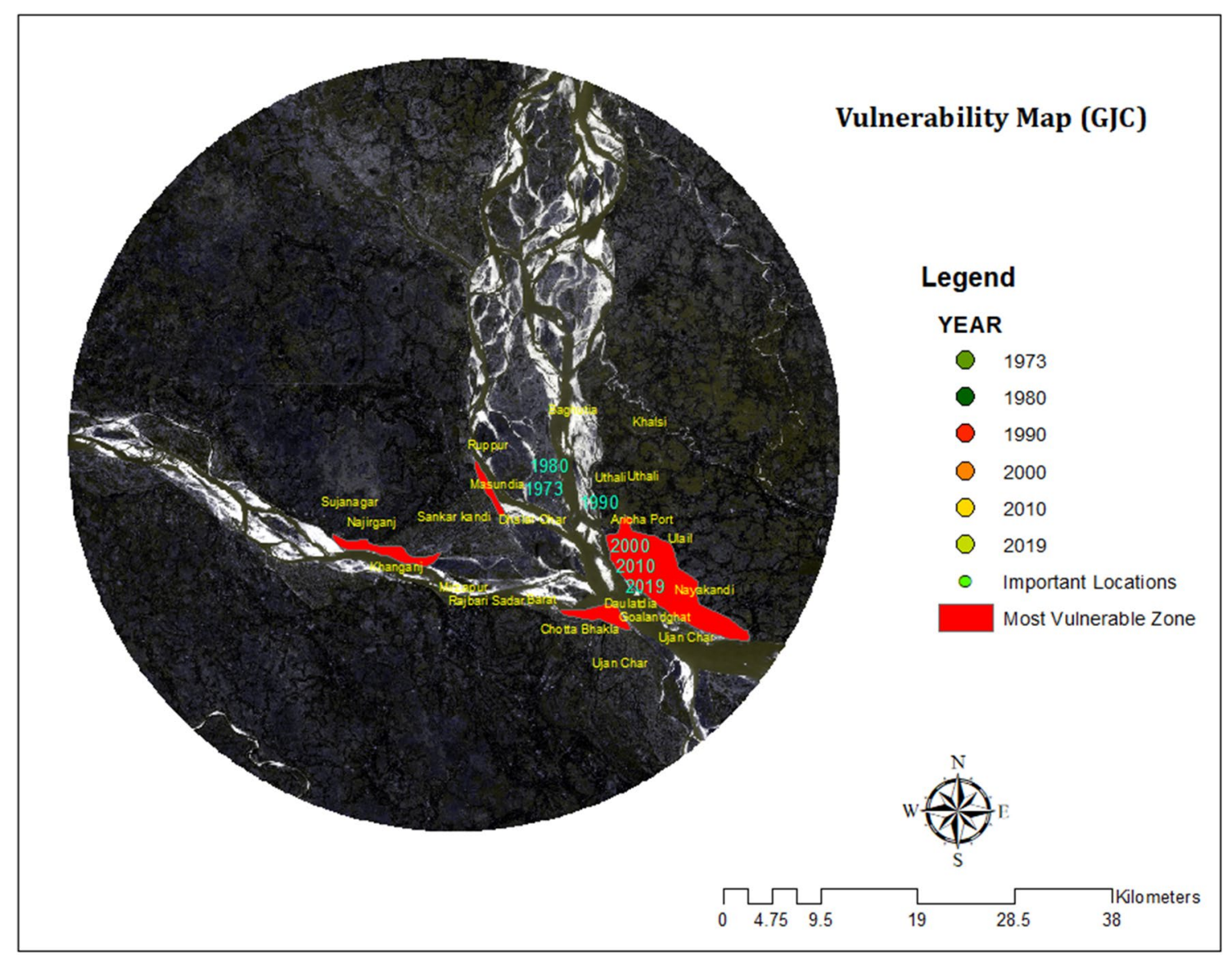

Fig. 11 Showing the most vulnerable zones around GJC due to shifting and erosional activities

\subsubsection{Erosion-Accretion Surrounding the GJC}

Erosional activities decreased from 1972 to 1990, then increased slightly up to 2000, and declined again from 2000 to 2010 (Fig. 9). But, in the recent decades, erosion was most at the GJC compared to accretion. Both rivers carry huge amount of sediments but a high-flow velocity impedes sediments to be deposited in this confluence zone. So, accretion is very active in the upper part of the confluence zone, whereas erosion is evident in the lower part of the confluence zone, as evidenced from the absence of any sandbar in the lower part (Fig. 10). So, it can be predicted that erosion is very prominent in the lower part of the confluence zone. Aricha Ghat, Daulatdia, Masundia, Khanganj, and Nayakandi regions are more vulnerable to erosion in and around the GJC (Fig. 11).

\section{Conclusion}

The planform morphodynamics of both river confluences showed a wide range of adjustments in case of channel changes, accretions (bar depositions), and erosions within the confluence zone, channels migrating within a defined belt via braiding. The confluences are highly mobile that migrate an order of magnitude greater than the channel width. PMC and GJC demonstrate the dynamic trend of the confluence Point shifting. GJC followed particular movement of the confluence point, whereas PMC did not. GJC confluence point was moved NW direction from year 1972 to 1980 but from 1980 to the present, the confluence is moving through SE direction. On the other hand, PMC confluence moved through NW direction from the year 1972 to 1980 but for the next 30 years, from 1980 to 2010, the confluence moved through SE direction and most importantly, from 2010 to present, the confluence point is moving through NW direction.

Confluence width in the PMC varied significantly throughout the study time frame. The calculated width was $6.87 \mathrm{~km}^{2}$, $12.64 \mathrm{~km}^{2}, 11.63 \mathrm{~km}^{2}, 9.37 \mathrm{~km}^{2}, 6.03 \mathrm{~km}^{2}, 6.98 \mathrm{~km}^{2}$, respectively, in the years of 1972, 1980, 1990, 2000, 2010, and 2019. But the GJC zone had been followed a decreasing trend of confluence width change over the 47 years, the confluence width declined from 8.10 to $2.80 \mathrm{~km}^{2}$. Sandbar area of the PMC increased from 1972 to 2019 over 47 years about 147.09 $\mathrm{km}^{2}$ and the increment was more than three times in 2019 than 
that of 1972. In contrast, GJC is showing a decreasing pattern where the total sandbar area decreased about $51.02 \mathrm{~km}^{2}$ from 1972 to 2019. From the analysis of erosion-accretion, it can be clearly predicted that erosion is very prominent in the recent decades from 2010 to 2019 around the both confluences. The left bank of lower Padma in the lower confluence area of PMC is highly vulnerable due to erosion and downstream part of the Ganges river, the left side of GJC confluence zone has been recognized as the most vulnerable zone.

The study has been successful in delineating the relationship between the dynamic nature of confluence and the vulnerability assessment of the PMC and GJC. The study could be taken as a reference in identifying the vulnerable zones and would help in further mapping and planning of Government projects or industrialization around the two major confluences (PMC and GJC).

Acknowledgements Thanks to the University Grant Commission (UGC) of Bangladesh for providing a fund to conduct the study. We are very thankful to the unanimous reviewers for their valuable comments and suggestions. The authors are also very grateful to the Department of Geology, University of Dhaka for providing laboratory facilities.

Open Access This article is licensed under a Creative Commons Attribution 4.0 International License, which permits use, sharing, adaptation, distribution and reproduction in any medium or format, as long as you give appropriate credit to the original author(s) and the source, provide a link to the Creative Commons licence, and indicate if changes were made. The images or other third party material in this article are included in the article's Creative Commons licence, unless indicated otherwise in a credit line to the material. If material is not included in the article's Creative Commons licence and your intended use is not permitted by statutory regulation or exceeds the permitted use, you will need to obtain permission directly from the copyright holder. To view a copy of this licence, visit http://creativecommons.org/licenses/by/4.0/.

\section{References}

Ahmed MH, Rezaie AM, Siddique MKB, Ahmed I (2014) Erosion trend analysis at Chandpur confluence of Meghna estuary. In: Proceedings of the 2nd International Conference on Civil Engineering for Sustainable Development (ICCESD-2014), 14 16, KUET, Khulna, Bangladesh.

Ali HL, Yusuf B, Mohammed TA, Shimizu Y, Ab Razak MS, Rehan BM (2019) Improving the hydro-morpho dynamics of a river confluence by using vanes. Resources 8(1):9

Ashworth PJ, Best JL, Roden JE, Bristow CS, Klaassen GJ (2000) Morphological evolution and dynamics of a large, sand braid-bar, Jamuna River. Bangladesh Sedimentol 47(3):533-555

Baranya S, Olsen NRB, Józsa J (2015) Flow analysis of a river confluence with field measurements and RANS model with nested grid approach. River Res Appl 31(1):28-41

Benda L, Andras K, Miller D, Bigelow P (2004) Confluence effects in rivers: Interactions of basin scale, network geometry, and disturbance regimes. Water Resour Res 40:1-15

Best JL, Rhoads B (2008) Sediment transport, bed morphology and the sedimentology of river channel confluences. In: Rice SP, Roy
AG, Rhoads B (eds) River confluences, tributaries and the fluvial network. John Wiley and Sons, Chichester, pp 45-72

Biron P, Roy AG, Best JL, Boyer CJ (1993) Bed morphology and sedimentology at the confluence of unequal depth channels. Geomorphology 8(2):115-129

Boyer C, Roy AG, Best JL (2006) Dynamics of a river channel confluence with discordant beds: flow turbulence, bed load sediment transport, and bed morphology. J Geophys Res. https://doi. org/10.1029/2005JF000458

CEGIS (2003) Morphological analysis and predictions for the Padma and Meghna rivers around Chandpur. CEGIS, Dhaka

Datta DK, Subramanian V (1998) Distribution and fractionation of heavy metals in the surface sediments of the Ganges-Brahmaputra-Meghna river system in the Bengal basin. Environ Geol 36(1-2):93-101

De Serres B, Roy AG, Biron PM, Best JL (1999) Three-dimensional structure of flow at a confluence of river channels with discordant beds. Geomorphology 26(4):313-335

Dixon SJ, Smith GHS, Best JL, Nicholas AP, Bull JM, Vardy ME, Goodbred S (2018) The planform mobility of river channel confluences: Insights from analysis of remotely sensed imagery. Earth Sci Rev 176:1-18

FAP 24 (1996) River Survey Project: bedforms and bar dynamics in the main rivers of Bangladesh. Special Report No. 9. Flood Action Plan, Water Resources Planning Organization, Dhaka

Gazi MY, Hossain F, Sadeak S, Uddin MM (2020) Spatiotemporal variability of channel and bar morphodynamics in the Gorai-Madhumati River, Bangladesh using remote sensing and GIS techniques. Front Earth Sci. https://doi.org/10.1007/s11707-020-0827-z

Ginsberg SS, Aliotta S, Lizasoain GO (2009) Morphodynamics and seismostratigraphy of a deep hole at tidal channel confluence. Geomorphology 104(3-4):253-261

Guillén-Ludeña S, Franca MJ, Cardoso AH, Schleiss AJ (2016) Evolution of the hydromorphodynamics of mountain river confluences for varying discharge ratios and junction angles. Geomorphology 255:1-15

Hackney C, Carling P (2011) The occurrence of obtuse junction angles and changes in channel width below tributaries along the Mekong River, south-east Asia. Earth Surf Proc Land 36(12):1563-1576

Hackney CR, Darby SE, Parsons DR, Leyland J, Aalto R, Nicholas AP, Best JL (2018) The influence of flow discharge variations on the morphodynamics of a diffluence-confluence unit on a large river. Earth Surf Proc Land 43(2):349-362

Halcrow (1993) Southwest area water resources management project. Volume 3. morphological studies, Sir Halcrow and Parterns with DHI, EPL, and SthapatiSangshad Ltd. Halcrow Group, London

IWM (2005) Morphological forecast during monsoon for monitoring and disaster preparedness for erosion protection of river Meghna at Chandpur. IWM, Dhaka

Julien PY, Ghani AA, Zakaria NA, Abdullah R, Chang CK (2010) Case study: flood mitigation of the Muda river, Malaysia. J HydraulEng 136:251-261

Leite MR, Blanckaert K, Roy AG, Schleiss AJ (2012) Hydromorphological implications of local tributary widening for river rehabilitation. Water Resour Res 48:W10528

Lewin J, Ashworth PJ (2014) Defining large river channel patterns: alluvial exchange and plurality. Geomorphology 215:83-98

Mohammed TA, Al-Hassoun S, Ghazali AH (2011) Prediction of flood levels along a stretch of the langat river with insufficient hydrological data. Pertanika J SciTechnol 19:237-248

Mosley MP (1976) An experimental study of channel confluences. J Geol 84:535-562

Mount NJ, Tate NJ, Sarker MH, Thorne CR (2013) Evolutionary, multi-scale analysis of river bank line retreat using continuous 
wavelet transforms: Jamuna River, Bangladesh. Geomorphology 183:82-95

Nath B, Naznin SN, Alak P (2013) Trends analysis of river bank erosion at Chandpur, Bangladesh: a remote sensing and GIS approach. Int J GeomatGeosci 3(3):454-463

Parsons DR, Best JL, Lane SN, Orfeo O, Hardy RJ, Kostaschuk R (2007) Form roughness and the absence of secondary flow in a large confluence-diffluence, Rio Paraná. Argent Earth Surf Process Landf 32(1):155-162

Parsons DR, Best JL, Lane SN, Kostaschuk RA, Hardy RJ, Orfeo O, Szupiany RN (2008) Large river channel confluences. River confluences, tributaries and the fluvial network. John Wiley and Sons, Chichester, pp 73-91

Rhoads BL, Johnson KK (2018) Three-dimensional flow structure, morphodynamics, suspended sediment, and thermal mixing at an asymmetrical river confluence of a straight tributary and curving main channel. Geomorphology 323:51-69

Richards KS (1980) A note on changes in channel geometry at tributary junctions. Water Resour Res 16(1):241-244

Sambrook Smith GH, Ashworth PJ, Best JL, Lunt IA, Orfeo O, Parsons DR (2009) The sedimentology and alluvial architecture of a large braid bar, Rio Parana. Argent J Sediment Res 79(8):629

Sankey JB, Kasprak A, Caster J, East AE, Fairley HC (2018) The response of source-bordering aeoliandunefields to sediment-supply changes 1: effects of wind variability and river-valley morphodynamics. Aeol Res 32:228-245

Sarker MH, Thorne CR (2006) Morphological response of the Brahmaputra-Padma-Lower Meghna river system to the Assam earthquake of 1950. Braided Rivers: process, deposits, ecology and management. Blackwell Publishing, Oxford, pp 289-310

Sarker MH, Huque I, Alam M, Koudstaal R (2003) Rivers, chars and char dwellers of Bangladesh. Int J River Basin Manag 1(1):61-80

Stevaux JC, Amâncio A, Etchebehere MLDC, Fujita RH (2009) Morphodynamics in the confluence of large regulated rivers: the case of Paraná and Paranapanema rivers. Lat Am J Sedimentol Basin Anal 16(2):101-109

SWMC (2002) Surveys and mathematical modelling to support the design work of gorai restoration project. SWMC, Dhaka

Szupiany RN, Amsler ML, Parsons DR, Best JL, Haydel R (2019) Comparisons of morphology and flow structure at two braid-bar confluences in a large river. River, coastal and estuarine morphodynamics: RCEM 2007, two volume set. CRC Press, London, pp 754-761

Trigg MA, Bates PD, Wilson MD, Schumann G, Baugh C (2012) Floodplain channel morphology and networks of the middle Amazon River. Water Resour Res. https://doi.org/10.1029/2012WR011888

Wang X, Wang H, Yan X, Liu X, Duan HF (2016) Experimental study on the hydrodynamic influence of river flow confluences to the open channel stage - discharge relationship. Preprints. https://doi. org/10.20944/preprints201610.0079.v1

Wasson RJ (2003) A sediment budget for the Ganga-Brahmaputra catchment. CurrSci 84:1041-1047

Wheaton JM, Brasington J, Darby SE, Kasprak A, Sear D, Vericat D (2013) Morphodynamic signatures of braiding mechanisms as expressed through change in sediment storage in a gravel-bed river. J Geophys Research 118(2):759-779

Xie Q, Yang J, Lundström S, Dai W (2018) Understanding morphodynamic changes of a tidal river confluence through field measurements and numerical modeling. Water 10(10):1424

Xu H (2006) Modification of normalized difference water index (NDWI) to enhance open water features in remotely sensed imagery. Int J Remote Sens 27:3025-3033 